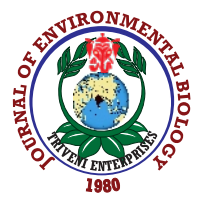

\title{
Morphological analysis and screening of wheat generations derived from HD2967 $\times$ Kharchia65 for salt tolerance
}

\author{
Varsha', S. Yashveer", V. Singh ${ }^{2}$ and P. Kumar ${ }^{2}$ \\ ${ }^{1}$ Department of Molecular Biology, Biotechnology and Bioinformatics, CCS Haryana Agricultural University, Hisar-125004, India \\ ${ }^{2}$ Department of Genetics and Plant Breeding, COA, CCS HaryanaAgricultural University, Hisar-125 004, India \\ *Corresponding Author Email : shikhayashveer@gmail.com
}

\section{Abstract}

Aim: To screen wheat generations derived from cross HD2967 × Kharchia65 for two Nax loci imparting salt tolerance and background selection of the plants using polymorphic SSRs.

Methodology: The study for salt tolerance was carried out on three generations, i.e., $\mathrm{BC}_{1} \mathrm{~F}_{3}, \mathrm{BC}_{2} \mathrm{~F}_{2}$ and $\mathrm{F}_{4}$, derived from the cross $\mathrm{HD} 2967 \times$ Kharchia65 in net house. Salt stress was provided at germination stage and the plants were grown to maturity. Data was recorded for various agro-morphological traits which contributed to yield. DNA isolated from young leaves of morphologically superior plants were checked for the presence of Nax1 and Nax2 genes using gene specific primers. Plants having either or both $\mathrm{Nax}$ loci were then subjected to polymorphic SSR markers screening for background selection of foreground selected plants.

Results: On the basis of agro-morphological performance and presence of either or both Nax genes, 68 high yielding plants were selected. Out of total 178 SSR markers screened covering the whole genome uniformly (A, B and D), 31 markers were polymorphic for the parents HD2967 and Kharchia65. These polymorphic SSR markers were used to produce molecular diversity among the selected progeny plants. Cluster analysis of parents and all the three generations, showed that all the selected plants were inclined towards recurrent parent.

Interpretation: This study showed that a linked marker like Nax1 and Nax2 could be a promising tool for breeding wheat with enhanced tolerance to salinity conditions. However, growth rates and biomass production provide reliable criteria for assessing the degree of salt stress and the ability of a plant to withstand it. Therefore, initial screening of seeds in the presence of salt stress provides additional advantage in directional selection. Plants selected with Nax loci, better

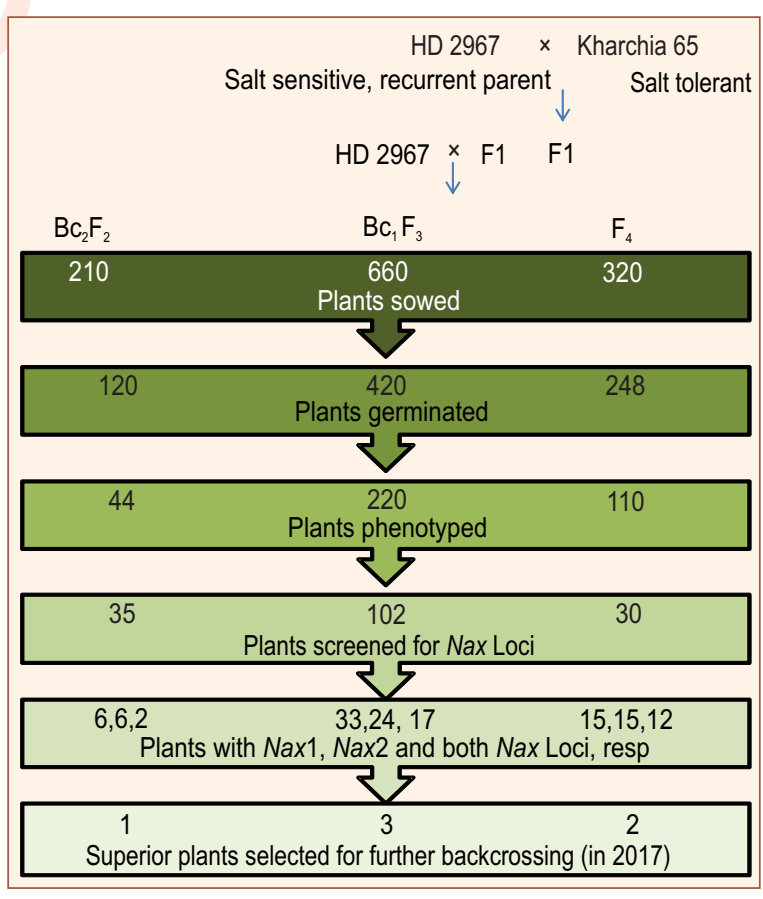
mean performances, high heritability, and high genetic advance as $5 \%$ of mean for the studied traits could be further backcrossed with the recurrent parent to develop salt tolerant wheat lines.

Key words: $\mathrm{Na}^{+}$exclusion, Nax genes, Salinity, Wheat

How to cite : Varsha, S. Yashveer, V. Singh and P. Kumar: Morphological analysis and screening of wheat generations derived from HD2967 × Kharchia 65 for salt tolerance. J. Environ. Biol., 41, 695-702 (2020). 


\section{Introduction}

Globally, wheat (Triticum aestivum L. em. Thell) is an important staple food crop and has been cultivated in major civilizations of Europe, West Asia, and North Africa. Today, wheat is grown on more land area than any other commercial crop, covering about 219 million ha with annual production of 760.3 million tons in 2017-18 (FAOSTAT, 2018). It continues to be the most important food grain source contributing about a fifth of total calories consumed by humans. Crop production has been threatened by changes in climate for the last few decades (Ahmad et al., 2010; Ahmad, 2012). The production of wheat has unveiled a significant reduction due to soil salinization year by year (Oyiga et al., 2016). Application of poor quality irrigation water and shallow saline groundwater contributes to the salinization of upper soil. These particular processes contributing to salinization, combined with the influence of other climatic and landscape features and the effects of human activities determines the accumulation of salt in the landscape (Rengasamy, 2010). Salinity adversely affects the cultivated land area and the salinized area is increasing because of unreasonable irrigation, unsustainable cultivation and climate change (Qadir et al., 2014; Jayakannan et al., 2015). Response of wheat plant to soil salinity is complex and depends on several factors like growth stage, concentration of salts in soil and type of salts (Khan etal., 2010).

Currently, two methods are being followed for managing the problem of salinity; first is transforming soil with chemical or physical methods and secondly cultivation of salt-tolerant varieties developed through biotechnology. The erstwhile is costly and raise the secondary salinization of soil and also adds up chemical substances. Therefore, cultivating salt-tolerant crop varieties is recommended. Attempts to improve salt tolerance of crops through traditional breeding programs have achieved little success due to genetic and physiological complexity of the trait. DNA markers are highly effective in identifying genes and selecting multi-genic traits and genes which are mainly influenced by environmental conditions. SSRs are being used for investigation, genetic divergence, genome and QTL mapping for salt tolerance in different crops (Liu et al., 2001; Munns, 2002; Ma et al., 2007; Kurup et al., 2009).

Alocus named, Kna1, for controlling $\mathrm{K}^{+} / \mathrm{Na}^{+}$discrimination in wheat has been identified on chromosome 4DL (Gorham et al., 1987; Shah et al., 1987; Dubcovsky et al., 1996; Gao et al., 2001). $\mathrm{Nax} 1$ and $\mathrm{Nax} 2$ are two genetic loci that control the removal of $\mathrm{Na}^{+}$ from the xylem and thereby help to exclude $\mathrm{Na}^{+}$from leaves of plants in saline soil. Nax1 removes $\mathrm{Na}^{+}$from the xylem in roots and lower parts of leaves, leaf sheaths, and is found to be located on chromosome 2A (Lindsay et al., 2004), while Nax2 is located on chromosome $5 \mathrm{~A}$ (Byrt et al., 2007) and removes $\mathrm{Na}^{+}$from the xylem, only in the roots (James et al., 2006). Since Nax genes are not present in modern wheat (Huang et al., 2006), molecular markers linked with Nax1 and Nax2 genes can be employed as an effective screening tool to overcome the salinity problem which limits the wheat production. Yadav et al. (2017) confirmed and validated the presence of Nax1 and Nax2 loci in Kharchia65 by using linked SSR markers. The present study therefore aimed at introgression of the genes for salt tolerance in HD2967 from Kharchia65 using conventional breeding methods and then screening the plants with linked markers for confirming the presence of introgressed genes. $\mathrm{BC}_{1} \mathrm{~F}_{3}, \mathrm{BC}_{2} \mathrm{~F}_{2}$ and $\mathrm{F}_{4}$ generations were selected using a combination of morphological parameters and molecular markers.

\section{Materials and Methods}

Raising of cross generations: A cross between well-known cultivar, HD2967 with good agronomic traits but susceptible to salinity and low yielding, otherwise tolerant to salinity and drought, Kharchia 65 was during 2012-13 and $F_{1}$ seeds were evaluated in the next season for phenotypic and molecular traits. Plants from $F_{1}$ progeny screened for Nax loci, using linked markers available plants with either both or any of Nax loci in combination with good yield under salt-stress conditions, were progressed to the next generation. Backcrossing of $F_{1}$ and elite parent (HD2967) was performed to obtain the $\mathrm{BC}_{1} \mathrm{~F}_{1}$ and continuous selfing of $F_{1}$ and $B C_{1} F_{1}$ led to $F_{4}$ and $B C_{1} F_{3}$ generations, respectively. Second backcross of $\mathrm{BC}_{1} \mathrm{~F}_{1}$ with the recurrent parent (2014-15) was made to obtain $\mathrm{BC}_{2} \mathrm{~F}_{1}$ generation and then further selfing gave $\mathrm{BC}_{2} \mathrm{~F}_{2}$ generation. Every year phenotypically superior plants were subjected to marker-assisted selection to obtain the next generations. The present study comprised of $\mathrm{BC}_{1} \mathrm{~F}_{3}, \mathrm{BC}_{2} \mathrm{~F}_{2}$ and $\mathrm{F}_{4}$ seeds of the cross.

The parental genotypes, backcrosses and $\mathrm{F}_{4}$ generations were raised during Rabi 2016-17 in trays in the net house of the Department of Molecular Biology, Biotechnology and Bioinformatics, CCS Haryana Agricultural University, Hisar, India. The seeds were subjected to chloride dominated salt stress (EC $8 \mathrm{ds} \mathrm{m}^{-1}$ ) at the time of germination. The seeds which germinated under salt stress were transplanted to pots with normal soil, i.e., deprived of salinity stress. Before transplanting, the original soil of the seedlings was neutralized by washing them in water and the plants growing in pots were given Hoagland nutrient solution every 10 days from the sowing date. The seedlings were grown to maturity and data was collected on various morphological traits like plant height, number of tillers per plant, spike length, number of grains per spike, number of spikelets per spike, 100-grain weight, grain yield per plant and biological yield per plant.

Isolation of Genomic DNA and SSRs screening: Whole genomic DNA was isolated from young leaf tissues of the selected morphologically superior progeny plants and parents using CTAB method (Saghai-Maroof et al., 1984). Parental DNA was amplified using 178 SSRs to study polymorphism. Phenotypically superior plants of all the generations were selected and checked for the presence of Nax loci using gene-specific SSR primers. Those having Nax loci were subjected to amplification using polymorphic SSRs for genotyping. PCR amplifications were performed using My-CYCLER (programmable thermal cycler 
from BIORAD ${ }^{\text {TM }}$ INTERNATIONAL). PCR reaction was conducted in a reaction volume of $20 \mu$ l containing 10X PCR buffer, $10 \mathrm{mM}$ dNTPs, $0.4 \mu \mathrm{M}$ of each primer, 1 unit Taq DNA polymerase and 50-80 ng template DNA. Amplified DNA products were resolved by submerged horizontal electrophoresis in $2.5 \%$ agarose gels, viewed under UV light fluorescence using Labnet Ultra violet trans-illuminator and image was taken by GenoSens Gel Doc system. The presence of DNA band on agarose gel was taken as one and the absence was read as zero.

Statistical Analyses: Morphological data was analyzed using INDOSTAT software. Molecular weights for SSR amplified products in base pairs were estimated and the summary statistical analysis of the genotypic data was performed using POWERMARKER software version 3.25 (Liu and Muse, 2005). Gene diversity, heterozygosity and polymorphism information content (PIC) values were calculated for each marker. Dendrogram for various generations were constructed using distance matrix by the unweighted pair-group method with arithmetic average (UPGMA) by POWERMARKER software version 3.25 and resultant files were visualized and edited using MEGA7.

\section{Results and Discussion}

In total, 1190 seeds were sown in the trays filled with soil and vermiculite mixture, out of which 220 plants of $\mathrm{BC}_{1} \mathrm{~F}_{3}, 44$ of $\mathrm{BC}_{2} \mathrm{~F}_{2}$ and 120 of $\mathrm{F}_{4}$ survived up to maturity and were harvested separately. Statistical analyses of recorded data revealed that the selection criterion was in the right direction as plants having $\mathrm{Nax}$ loci showed better performance over HD2967 in each generation under saline condition. The perusal of data (Tables 1, 2 and 3) revealed that under salinity various genetic parameters, i.e., GCV, PCV, heritability, and genetic advance as $5 \%$ of mean reported more influence of plant's genetic background and less of the environment. The highest GCV and PCV was reported for the grain yield per plant in $\mathrm{BC}_{1} \mathrm{~F}_{3}$ and $\mathrm{F}_{4}$ generations, while in $\mathrm{BC}_{2} \mathrm{~F}_{2}$, the number of tillers per plant showed the highest GCV and PCV. Among all the three generations, higher to moderate heritability was reported for all the traits, except for number of tillers per plant in $\mathrm{BC}_{1} \mathrm{~F}_{3}$.

Genetics advance estimates were highest for grain yield per plant in each generation during the study period, and higher to moderate genetic advance were reported for biological yield per plant, harvest index and number of tillers per plant. ljaz and Shahzad (2015) evaluated important quantitative traits and found a similar pattern of GCV, PCV, and heritability for plant height, spike length and number of spikelets per spike, grain yield per plant and biological yield. Ahmed et al. (2016) also reported higher heritability estimates for most of the traits in entire cross combinations of his study. Yadav et al. (2017) reported confirmatory results in the backcross generation of the cross HD2851 x Kharchia 65. Direct selection can be done for improving the traits showing higher heritability values with high genetic advance as traits with higher heritability are less affected by environment and there would be greater correspondence between phenotypic and breeding values (Panse, 1957).

Selection of plants based on the phenotypic trait is limited and can be misleading due to variation in soil salinity and sodicity, hence marker-assisted selection approach is more effective (Ma et al., 2007). Molecular markers are indispensable tools for improving plant breeding methods by facilitating early selection through linked genes of interest and also they have been profusely used for investigation of molecular breeding, genome mapping, and QTL mapping for biotic and abiotic tolerance in various crops (Liu et al., 2001; Munns et al., 2002; Ma et al., 2007; Kurup et al., 2009). These markers are not influenced by the environment and can be scored at all stages of plant growth, which saves time, resources and energy. SSRs linked to Nax1 ( $5^{\prime}-$ ATCGCATGATGCACG-3') and Nax2 (5'TCTCCATCATTCATC-3') loci gave amplification in Kharchia 65 only (Fig. 1) when used to amplify genomic DNA of both parents. One hundred seventy-eight SSR primers other than Nax1 and Nax2 were then used to study polymorphism between parents, out of which 31 SSRs were found to be polymorphic. Out of 384

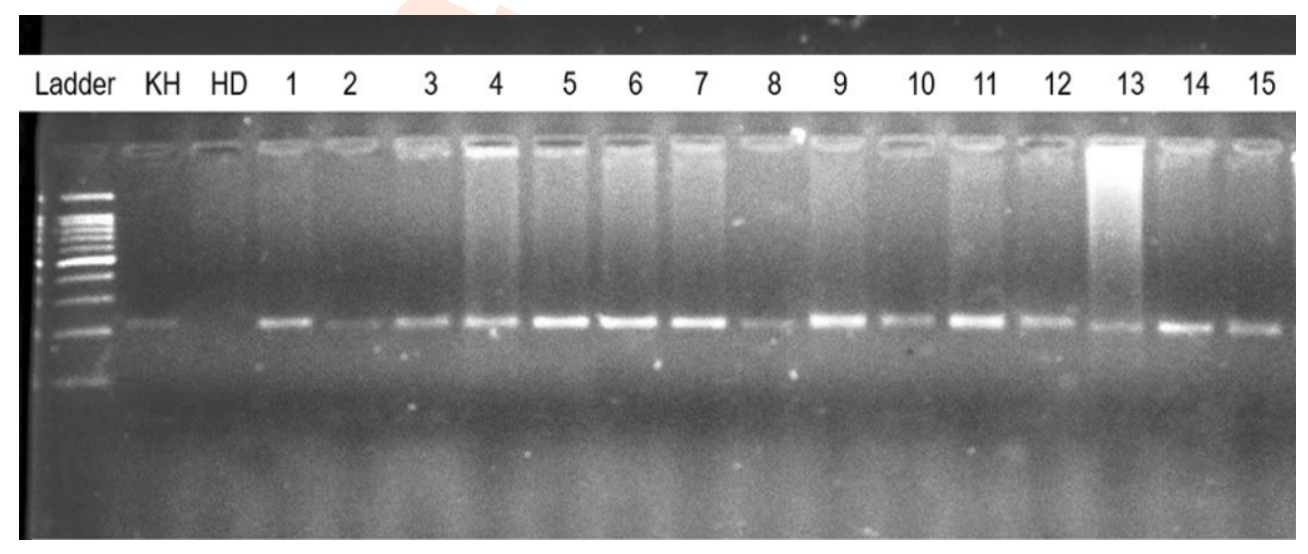

Fig. 1: Nax1 banding pattern in Kharchia $65(\mathrm{KH}), \mathrm{HD} 2967(\mathrm{HD})$ and $\mathrm{F}_{4}$ plants (1-15). 

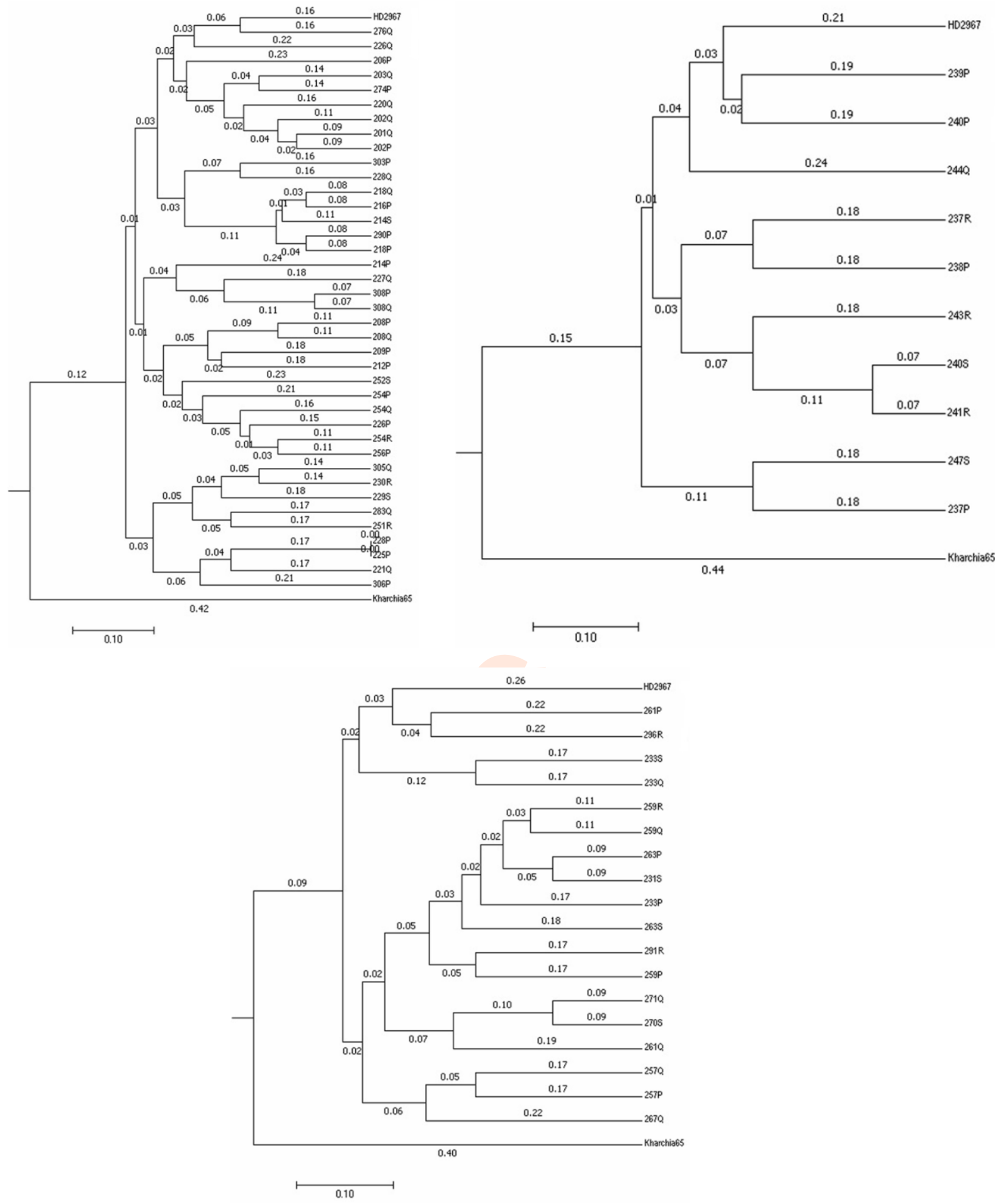

Fig. 2: Dendrogram showing relationship among (a) parents and $B C_{1} F_{3}$ plants; (b) parents and $B C_{2} F_{2}$ plants and $(c) F_{4}$ plants at 31 polymorphic loci.

plants, 167 phenotypically superior plants were selected from three generations to be screened for Nax loci. Sixty-eight plants confirmed the presence of either Nax 1 at a band size of 210 base pairs or Nax2 at a band size of 225 base pairs or both Nax loci.
These plants were then screened using 31 polymorphic SSRs. Abbasov et al. (2011) reported similar banding pattern for the Nax loci while studying Turkish wheat accessions. Yadav et al. (2017) obtained affirmative results in $\mathrm{F}_{2}$ generation of cross HD2852 $\times$ 
Table 1: Mean, Range, GCV, PCV, $\mathrm{H}^{2}$ and Genetic advance ( $\%$ of mean) for various traits in $\mathrm{BC}^{1} \mathrm{~F}^{3}$ population

\begin{tabular}{|c|c|c|c|c|c|c|}
\hline \multirow{3}{*}{ Traits } & \multicolumn{6}{|c|}{$\mathrm{BC}_{1} \mathrm{~F}_{3}$} \\
\hline & \multicolumn{3}{|c|}{ Phenotypic parameters } & \multicolumn{3}{|c|}{ Genetic parameters } \\
\hline & Mean \pm SE & Range & $\begin{array}{l}\text { GCV } \\
(\%)\end{array}$ & $\begin{array}{l}\text { PCV } \\
(\%)\end{array}$ & $\begin{array}{l}\text { Heritability } \\
(\%)\end{array}$ & $\begin{array}{l}\text { Genetic advance } \\
\text { as } 5 \% \text { of mean }\end{array}$ \\
\hline Plant height (cm) & $80.57 \pm 0.51$ & $55.00-119.50$ & 9.92 & 29.48 & 67.00 & 12.14 \\
\hline No. of tillers /plant & $2.71 \pm 0.05$ & $1.00-6.00$ & 27.01 & 36.64 & 27.10 & 59.11 \\
\hline Spike length (cm) & $10.02 \pm 0.10$ & $6.50-15.00$ & 17.31 & 21.48 & 66.00 & 38.72 \\
\hline Number of spikelets/spike & $14.85 \pm 0.16$ & $7.00-25.00$ & 18.21 & 27.98 & 60.20 & 31.03 \\
\hline Number of grains /spike & $41.14 \pm 0.68$ & $8.00-70.00$ & 27.11 & 28.38 & 78.10 & 37.32 \\
\hline 100 grain weight $(\mathrm{g})$ & $3.99 \pm 0.04$ & $2.30-9.55$ & 17.11 & 22.43 & 63.60 & 38.28 \\
\hline Grain yield/ plant (g) & $3.36 \pm 0.07$ & $0.35-6.85$ & 36.85 & 47.92 & 72.10 & 57.70 \\
\hline Biological yield/ plant (g) & $9.15 \pm 0.18$ & $2.01-18.90$ & 31.78 & 41.09 & 73.20 & 51.63 \\
\hline Harvest index $(\%)$ & $36.69 \pm 0.46$ & $17.41-49.52$ & 20.08 & 21.57 & 50.30 & 34.39 \\
\hline
\end{tabular}

Table 2: Mean, Range, GCV, PCV, $\mathrm{H}^{2}$ and Genetic advance (\% of mean) for various traits in $\mathrm{BC}^{2} \mathrm{~F}^{3}$ population

\begin{tabular}{|c|c|c|c|c|c|c|}
\hline \multirow{3}{*}{ Traits } & \multicolumn{6}{|c|}{$\mathrm{BC}_{2} \mathrm{~F}_{2}$} \\
\hline & \multicolumn{3}{|c|}{ Phenotypic parameters } & \multicolumn{3}{|c|}{ Genetic parameters } \\
\hline & Mean \pm SE & Range & $\begin{array}{l}\text { GCV } \\
(\%)\end{array}$ & $\begin{array}{l}\text { PCV } \\
(\%)\end{array}$ & $\begin{array}{l}\text { Heritability } \\
(\%)\end{array}$ & $\begin{array}{l}\text { Genetic advance } \\
\text { as } 5 \% \text { of mean }\end{array}$ \\
\hline Plant height (cm) & $81.89 \pm 0.96$ & $70.50-96.50$ & 7.78 & 17.93 & 68.80 & 11.95 \\
\hline No. of tillers /plant & $2.75 \pm 0.23$ & $1.00-8.00$ & 54.40 & 61.32 & 64.70 & 44.97 \\
\hline Spike length $(\mathrm{cm})$ & $10.60 \pm 0.36$ & $6.20-16.60$ & 22.77 & 24.64 & 55.30 & 23.33 \\
\hline Number of spikelets/spike & $16.54 \pm 0.56$ & $9.00-27.00$ & 22.40 & 24.15 & 78.00 & 32.81 \\
\hline Number of grains /spike & $41.15 \pm 1.47$ & $22.00-66.00$ & 23.73 & 24.15 & 66.50 & 48.03 \\
\hline 100 grain weight(g) & $3.84 \pm 0.09$ & $2.91-4.92$ & 15.18 & 15.99 & 70.20 & 29.71 \\
\hline Grain yield/ plant(g) & $3.23 \pm 0.19$ & $1.25-5.68$ & 38.88 & 45.21 & 64.00 & 52.49 \\
\hline Biological yield/ plant(g) & $9.36 \pm 0.52$ & $2.99-17.80$ & 36.76 & 38.40 & 71.60 & 48.90 \\
\hline Harvest index $(\%)$ & $35.03 \pm 1.18$ & $21.26-48.27$ & 22.33 & 22.93 & 54.90 & 44.82 \\
\hline
\end{tabular}

Kharchia 65. Munns et al. (2012) showed that the presence of Nax2 could increase the grain yield of wheat on salt-affected farmers' fields by up to $25 \%$. Xu et al. (2018) proposed that the underlying transport properties of TmHKT1;5-A and TaHKT1;5-D contribute to their unique ability to improve $\mathrm{Na}^{+}$exclusion in wheat that leads to improved salinity tolerance in the field. Fine mapping of the Nax1 locus indicated that the candidate gene was TmHKT1;4-A2 (Huang et al., 2006), which likely encodes for a $\mathrm{Na}^{+}$-specific transporter located on the plasma membrane of cells surrounding xylem vessels (Munns et al., 2012). Polymorphic SSRs, providing uniform coverage of all three wheat genomes (12, 8 and 11 markers on A, B, and D chromosome, respectively) were used for background selection of 68 selected plants from all three generations. Molecular marker analysis of selected plants using polymorphic SSRs revealed that these plants either had alleles in homozygous state or heterozygous state at varying frequencies.

The major allele frequency ranged from 0.500 to 0.926 in $\mathrm{BC}_{1} \mathrm{~F}_{3}, 0.458$ to 0.916 for $\mathrm{BC}_{2} \mathrm{~F}_{2}$ and 0.500 to 900 for $\mathrm{F}_{4}$ generation.
Gene diversity for the screened generations varied from 0.135 to 0.618 for $\mathrm{BC}_{1} \mathrm{~F}_{3}, 0.152$ to 0.611 for $\mathrm{BC}_{2} \mathrm{~F}_{2}$ and 0.180 to 0.605 for $\mathrm{F}_{4}$ generation. Out of 31 polymorphic SSRs, four SSRs (Barc 344, Wmc11, Wmc88 and Xcfd7) were heterozygous for all the three generations, while Xgwm577 was heterozygous only for $\mathrm{BC}_{1} \mathrm{~F}_{3}$ plants. The PIC values ranged from 0.118 (wmc11) to 0.500 (wmc577) with an average value of 0.381 (Table 4). De Bustos et al. (2001) developed gene-specific markers to assist selection in backcross progenies in Spanish wheat, and for recovering the genetic background of recurrent parent, selection was also done by other polymorphic markers (AFLPs) located across the complete genome of wheat. James et al. (2012) reported similar results after introgression of salinity tolerance genes from durum to bread wheat.

The range of major allele, PIC and gene diversity in all three generations of the present study showed that selected plants were significantly variable at genetic level too. Homozygosity of most of the markers in both backcrossed generations confirmed the recovery of recurrent parent's genome. 
Table 3: Mean, Range, GCV, PCV, $\mathrm{H}^{2}$ and Genetic advance (\% of mean) for various traits in $\mathrm{F}_{4}$ population

\begin{tabular}{|c|c|c|c|c|c|c|}
\hline \multirow{3}{*}{ Traits } & \multicolumn{6}{|c|}{$\mathrm{F}_{4}$} \\
\hline & \multicolumn{3}{|c|}{ Phenotypic parameters } & \multicolumn{3}{|c|}{ Genetic parameters } \\
\hline & Mean \pm SE & Range & $\begin{array}{l}\text { GCV } \\
(\%)\end{array}$ & $\begin{array}{l}\text { PCV } \\
(\%)\end{array}$ & $\begin{array}{l}\text { Heritability } \\
(\%)\end{array}$ & $\begin{array}{l}\text { Genetic advance } \\
\text { as } 5 \% \text { of mean }\end{array}$ \\
\hline Plant height (cm) & $80.21 \pm 1.01$ & $50.80-106.50$ & 12.09 & 22.46 & 63.10 & 12.79 \\
\hline No. of tillers /plant & $3.06 \pm 0.11$ & $1.00-7.00$ & 32.91 & 39.33 & 52.90 & 38.53 \\
\hline Spike length $(\mathrm{cm})$ & $10.36 \pm 0.24$ & $4.30-18.00$ & 23.97 & 25.05 & 75.30 & 25.22 \\
\hline Number of spikelets/ spike & $14.61 \pm 0.29$ & $7.00-23.00$ & 20.56 & 23.09 & 69.23 & 37.70 \\
\hline Number of grains /spike & $37.10 \pm 1.31$ & $3.00-66.00$ & 36.04 & 36.12 & 68.50 & 36.70 \\
\hline 100 Grain Weight (g) & $3.71 \pm 0.05$ & $2.59-4.84$ & 14.31 & 16.67 & 73.60 & 25.29 \\
\hline Grain yield/ plant(g) & $3.07 \pm 0.16$ & $0.42-10.08$ & 55.57 & 59.77 & 66.50 & 63.46 \\
\hline Biological yield/ plant(g) & $9.02 \pm 0.33$ & $2.60-21.90$ & 37.37 & 39.89 & 74.80 & 52.12 \\
\hline Harvest index (\%) & $32.90 \pm 0.90$ & $12.87-51.64$ & 27.88 & 28.40 & 76.40 & 46.38 \\
\hline
\end{tabular}

Table 4: Summary statistics for all three generations of the cross

\begin{tabular}{|c|c|c|c|c|c|c|c|c|c|c|c|c|}
\hline & & BC1F3 & & & & $\mathrm{BC} 2 \mathrm{~F} 2$ & & & & F4 & & \\
\hline Marker & $\begin{array}{l}\text { Major } \\
\text { allele } \\
\text { frequency }\end{array}$ & $\begin{array}{l}\text { Gene } \\
\text { diversity }\end{array}$ & $\begin{array}{l}\text { Heterozy } \\
\text { gosity }\end{array}$ & PIC & $\begin{array}{l}\text { Major } \\
\text { allele } \\
\text { frequency }\end{array}$ & $\begin{array}{l}\text { Gene } \\
\text { diversity }\end{array}$ & Heterozygosity & PIC & $\begin{array}{l}\text { Major } \\
\text { allele } \\
\text { frequency }\end{array}$ & $\begin{array}{l}\text { Gene } \\
\text { diversity }\end{array}$ & Heterozygosity & PIC \\
\hline Barc26 & 0.7317 & 0.3926 & 0.0000 & 0.315 & 0.8333 & 0.2778 & 0.0000 & 0.239 & 0.8000 & 0.3200 & 0.0000 & 0.268 \\
\hline Barc310 & 0.6098 & 0.4759 & 0.0000 & 0.362 & 0.5833 & 0.4861 & 0.0000 & 0.368 & 0.5000 & 0.5000 & 0.0000 & 0.375 \\
\hline Barc344 & 0.6341 & 0.4640 & 0.2439 & 0.356 & 0.8333 & 0.2778 & 0.1667 & 0.239 & 0.6250 & 0.4688 & 0.1500 & 0.358 \\
\hline Barc263 & 0.5122 & 0.4997 & 0.0000 & 0.374 & 0.7500 & 0.3750 & 0.0000 & 0.304 & 0.7500 & 0.3750 & 0.0000 & 0.304 \\
\hline Wmc3 & 0.8049 & 0.3141 & 0.0000 & 0.264 & 0.5833 & 0.4861 & 0.0000 & 0.368 & 0.8000 & 0.3200 & 0.0000 & 0.268 \\
\hline Wmc382 & 0.7073 & 0.4140 & 0.0000 & 0.328 & 0.8333 & 0.2778 & 0.0000 & 0.239 & 0.6500 & 0.4550 & 0.0000 & 0.351 \\
\hline Wmc11 & 0.5000 & 0.5922 & 1.0000 & 0.509 & 0.4583 & 0.6111 & 1.0000 & 0.534 & 0.5000 & 0.6050 & 1.0000 & 0.527 \\
\hline Wmc46 & 0.7317 & 0.3926 & 0.0000 & 0.315 & 0.6667 & 0.4444 & 0.0000 & 0.345 & 0.7000 & 0.4200 & 0.0000 & 0.331 \\
\hline Wmc134 & 0.5122 & 0.4997 & 0.0000 & 0.374 & 0.5000 & 0.5000 & 0.0000 & 0.375 & 0.7000 & 0.4200 & 0.0000 & 0.331 \\
\hline Wmc145 & 0.5610 & 0.4926 & 0.0000 & 0.371 & 0.5833 & 0.4861 & 0.0000 & 0.368 & 0.7000 & 0.4200 & 0.0000 & 0.331 \\
\hline Wmc304 & 0.6341 & 0.4640 & 0.0000 & 0.356 & 0.7500 & 0.3750 & 0.0000 & 0.304 & 0.7000 & 0.4200 & 0.0000 & 0.331 \\
\hline Wmc41 & 0.7561 & 0.3688 & 0.0000 & 0.300 & 0.5000 & 0.5000 & 0.0000 & 0.375 & 0.6000 & 0.4800 & 0.0000 & 0.364 \\
\hline Wmc47 & 0.6341 & 0.4640 & 0.0000 & 0.356 & 0.6667 & 0.4444 & 0.0000 & 0.345 & 0.6000 & 0.4800 & 0.0000 & 0.364 \\
\hline Wmc758 & 0.6341 & 0.4640 & 0.0000 & 0.356 & 0.9167 & 0.1528 & 0.0000 & 0.141 & 0.6500 & 0.4550 & 0.0000 & 0.351 \\
\hline Wmc437 & 0.8049 & 0.3141 & 0.0000 & 0.264 & 0.5000 & 0.5000 & 0.0000 & 0.375 & 0.6000 & 0.4800 & 0.0000 & 0.364 \\
\hline Wmc719 & 0.5122 & 0.6187 & 0.0000 & 0.549 & 0.5833 & 0.4861 & 0.0000 & 0.368 & 0.6000 & 0.4800 & 0.0000 & 0.364 \\
\hline Wmc67 & 0.6341 & 0.4640 & 0.0000 & 0.356 & 0.5833 & 0.4861 & 0.0000 & 0.368 & 0.6500 & 0.4550 & 0.0000 & 0.351 \\
\hline Wmc577 & 0.6341 & 0.4640 & 0.0000 & 0.356 & 0.8333 & 0.2778 & 0.0000 & 0.239 & 0.6500 & 0.4550 & 0.0000 & 0.351 \\
\hline Wmc88 & 0.7439 & 0.3810 & 0.5122 & 0.308 & 0.7917 & 0.3299 & 0.4167 & 0.275 & 0.7000 & 0.4200 & 0.6000 & 0.331 \\
\hline Wmc104 & 0.6341 & 0.4640 & 0.0000 & 0.356 & 0.6667 & 0.4444 & 0.0000 & 0.345 & 0.6000 & 0.4800 & 0.0000 & 0.364 \\
\hline Wmc161 & 0.8537 & 0.2499 & 0.0000 & 0.218 & 0.6667 & 0.4444 & 0.0000 & 0.345 & 0.9000 & 0.1800 & 0.0000 & 0.163 \\
\hline Wmc428 & 0.9268 & 0.1356 & 0.0000 & 0.126 & 0.6667 & 0.4444 & 0.0000 & 0.345 & 0.9000 & 0.1800 & 0.0000 & 0.163 \\
\hline Wmc93 & 0.8537 & 0.2499 & 0.0000 & 0.218 & 0.5833 & 0.4861 & 0.0000 & 0.368 & 0.8500 & 0.2550 & 0.0000 & 0.222 \\
\hline Wmc48 & 0.9024 & 0.1761 & 0.0000 & 0.160 & 0.9167 & 0.1528 & 0.0000 & 0.141 & 0.8500 & 0.2550 & 0.0000 & 0.222 \\
\hline Xcfd7 & 0.7561 & 0.3688 & 0.4878 & 0.300 & 0.7083 & 0.4132 & 0.5833 & 0.327 & 0.6000 & 0.4800 & 0.8000 & 0.364 \\
\hline Xgwm46 & 0.5610 & 0.4926 & 0.0000 & 0.371 & 0.9167 & 0.1528 & 0.0000 & 0.141 & 0.8500 & 0.2550 & 0.0000 & 0.222 \\
\hline Xgwm577 & 0.7317 & 0.3989 & 0.0244 & 0.328 & 0.5000 & 0.5000 & 0.0000 & 0.375 & 0.7500 & 0.3750 & 0.0000 & 0.304 \\
\hline Xgwm480 & 0.7805 & 0.3427 & 0.0000 & 0.283 & 0.8333 & 0.2778 & 0.0000 & 0.239 & 0.6000 & 0.4800 & 0.0000 & 0.364 \\
\hline Xgwm443 & 0.6829 & 0.4331 & 0.0000 & 0.339 & 0.5833 & 0.4861 & 0.0000 & 0.368 & 0.6500 & 0.4550 & 0.0000 & 0.351 \\
\hline Xgwm455 & 0.6829 & 0.4331 & 0.0000 & 0.339 & 0.6667 & 0.4444 & 0.0000 & 0.345 & 0.6500 & 0.4550 & 0.0000 & 0.351 \\
\hline Xpsp3000 & 0.6585 & 0.4497 & 0.0000 & 0.348 & 0.7500 & 0.3750 & 0.0000 & 0.304 & 0.7000 & 0.4200 & 0.0000 & 0.331 \\
\hline Mean & 0.6876 & 0.4108 & 0.0732 & 0.328 & 0.6841 & 0.3999 & 0.0699 & 0.316 & 0.6895 & 0.4096 & 0.0823 & 0.324 \\
\hline
\end{tabular}


Separate dendrograms were prepared for all three generations by UPGMA method. Each of the three generations was grouped into two clusters. Major cluster I consisted of Kharchia 65 while cluster II contained all plants of respective progeny with the parent genotype HD2967 (Fig. 2). The finest breeding strategy is to select high yield under non-saline conditions followed by backcross of the selected plants. The genotype with higher productivity at lowest salinity should be used as recurrent parent. Though, in this study, plants were selected under saline conditions they showed that linked markers, i.e., Nax1 and Nax2 could present a valuable tool for breeding wheat with improved tolerance to salinity.

\section{References}

Abbasov, M., Z.I. Akparov, K. Street, R. Jafarova, F. Sheykzamanova, S. Rzayeva, S. Babayeva and R. Munns: Molecular physiological testing of diploid wheats (T. monococcum, $T$. boeoticum and $T$. urartu) to salinity stress. In: International Conference "Diversity, characterization and utilization of plant genetic resources for enhanced resilience to climate change". Baku, Azerbaijan, p. 119121 (2011).

Ahmed, N., M.A. Chowdhry, I. Khaliq and M. Maekawa: The inheritance of yield and yield components of five wheat hybrid populations under drought conditions. Indonesian. J. Agri. Sci., 8, 53-59 (2016).

Ahmad, P.: Salt-induced changes in photosynthetic activity and oxidative defense system of three cultivars of mustard (Brassica juncea L.). Afr. J. Biotechnol., 11, 2694-2703 (2012).

Ahmad, P., C.A. Jaleel, M.A. Salem, G. Nabi and S. Sharma: Roles of enzymatic and non enzymatic antioxidants in plants during abiotic stress. Crit. Rev. Biotech., 30, 161-175 (2010).

Byrt, C.S., J.D. Platten, W. Spielmeyer, R.A. James, E.S. Lagudah, E.S. Dennis, M. Tester and R. Munns: HKT1; 5-like cation transporters linked to $\mathrm{Na}^{+}$exclusion loci in wheat, Nax2 and Kna1. Plant Physio., 143, 1918-1928 (2007).

De Bustos, A., P.Rubio, C. Soler, P. Garcia and N. Jouve: Marker assisted selection to improve HMW-glutenins in wheat. In Wheat in a Global environment. Springer, Dordrecht, pp. 171-176 (2001).

Diaguna, R., F.C. Suwarno and M. Surahman: Testing method for salinity tolerance at germination stage on rice genotypes. Int. J. Appl. Sci. Tech., 7, 69-76 (2017)

Dubcovsky, J., G. Santa Maria, E. Epstein, M.C. Luo and J. Dvořák: Mapping of the $\mathrm{K}^{+} / \mathrm{Na}^{+}$discrimination locus Kna1 in wheat. Theor. Appl. Gene., 92, 448-454 (1996).

Food and Agriculture Organization of the United Nations: FAOSTAT. Website http://www.fao.org/faostat/ en/ (2018).

Gao, M.J., J. Dvorak and R. Travis: Expression of the extrinsic 23-kDa protein of photosystem II in response to salt stress is associated with the $\mathrm{K}^{+} / \mathrm{Na}^{+}$discrimination locus Kna1 in wheat. Plant Cell Rep., 20,774-778 (2001).

Gorham, J., C. Hardy, R.W. Jones, L.R. Joppa and C.N. Law: Chromosomal location of a K/Na discrimination character in the $\mathrm{D}$ genome of wheat. Theor. Appl. Gen., 74, 584-588 (1987).

Haq, T.U., J. Gorham, J. Akhtar, N. Akhtar and K.A. Steele: Dynamic quantitative trait loci for salt stress components on chromosome 1 of rice. Func. Plant Biol., 37, 634-645 (2010).

Hasan, M.M., M.A. Baque, M.A. Habib, M. Yeasmin and M.A. Hakim: Screening of salt tolerance capability of wheat genotypes under salt stress condition. Universal. J. Agri. Res., 5, 235-249 (2017).

Huang, S., W. Spielmeyer, E.S. Lagudah, R.A. James, J.D. Platten, E.S.
Dennis and R. Munns: A sodium transporter (HKT7) is a candidate for Nax1, a gene for salt tolerance in durum wheat. Plant Physio., $142,1718-1727$ (2006)

ljaz, F., I. Khaliq and M.T. Shahzad: Estimation of heritability for some yield contributing traits in $\mathrm{F}_{2}$ populations of bread wheat (Triticum aestivum L.). J. Agri. Res., 53, 157-164 (2015).

James, R.A., C. Blake, A.B. Zwart, R.A. Hare, A.J. Rathjen and R. Munns: Impact of ancestral wheat sodium exclusion genes Nax1 and Nax2 on grain yield of durum wheat on saline soils. Func. Plant. Biol., 39, 609-618 (2012).

James, R.A., R.J. Davenport and R. Munns: Physiological characterization of two genes for $\mathrm{Na}^{+}$exclusion in durum wheat, Nax1 and Nax2. Plant Physiol., 142, 1537- 1547 (2006).

James, R.A., C. Blake, C.S. Byrt and R. Munns: Major genes for $\mathrm{Na}^{+}$ exclusion, Nax1 and Nax2 (wheat HKT1; 4 and HKT1; 5), decrease $\mathrm{Na}^{+}$accumulation in bread wheat leaves under saline and waterlogged conditions. J. Experi. Bot., 62, 2939-2947 (2012).

Jayakannan, M., J. Bose, O. Babourina, Z. Rengel and S. Shabala: Salicylic acid in plant salinity stress signalling and tolerance. Plant Growth Regul., 76, 25-40 (2015).

Khan, A.J., F. Azam and A. Ali: Relationship of morphological traits and grain yield in recombinant inbred wheat lines grown under drought conditions. Pak. J. Bot., 42, 259-267 (2010).

Kurup, S.S., Y.S. Hedar, M.A. Al Dhaheri, A.Y. El-Heawiety, M.A. Aly and G. Alhadrami: Morpho-physiological evaluation and RAPD markers-assisted characterization of date palm (Phoenix dactylifera L.) varieties for salinity tolerance. J. Food Agricul. Environ., 7, 3-50 (2009).

Lindsay, M.P., E.S. Lagudah, R.A. Hare and R. Munns: Alocus for sodium exclusion (Nax1), a trait for salt tolerance, mapped in durum wheat. Funct. Plant Biol., 31, 1105-1114 (2004).

Liu, K. and S.V. Muse: Powermarker: integrated analysis environment for genetic markers data. Bioinformatics, 21, 2128-2129 (2005).

Liu, X., J. Shi, X. Zhang, Y. Ma and J. Jia: Screening salt tolerance germplasms and tagging the tolerance gene (s) using microsatellite (SSR) markers in wheat. Acta Botanica Sinica, 43, 948-954 (2001).

Ma, L., E. Zhou, N. Huo, R. Zhou, G. Wang and J. Jia: Genetic analysis of salt tolerance in a recombinant inbred population of wheat (Triticum aestivum L.). Euphytica, 153, 109-117 (2007).

Munns, R.: Comparative physiology of salt and water stress. Plant Cell. Envi., 25, 239-250 (2002).

Munns, R. and M. Tester: Mechanisms of salinity tolerance. Annu. Rev. Plant Biol., 59, 651-681 (2008).

Munns, R., R.A. James, B. Xu, A. Athman, S.J. Conn, C. Jordans, C.S. Byrt, R.A. Hare, S.D. Tyerman, M. Tester and D. Plett: Wheat grain yield on saline soils is improved by an ancestral $\mathrm{Na}^{+}$transporter gene. Nature Biotech., 30, 360 (2012).

Naik, V.R., S.S. Biradar, A. Yadawad, S.A. Desai and B.A. Veeresha: Study of genetic variability parameters in bread wheat (Triticum aestivum L.) genotypes. Res. J. Agric. Sci, 6, 123-125 (2015).

Oyiga, B. C., R. C. Sharma, J. Shen, M. Baum, F. C. Ogbonnaya, J. Léon and $A$. Ballvora: Identification and characterization of salt tolerance of wheat germplasm using a multivariable screening approach. J. Agro. Crop. Sci., 202, 472-485 (2016).

Oyiga, B. C., R. C. Sharma, M. Baum, F. C. Ogbonnaya, J. Léon and A. Ballvora: Allelic variations and differential expressions detected at quantitative trait loci for salt stress tolerance in wheat. Plant Cell. Envir., 41, 919-935 (2018).

Panse, V.G.: Genetics of quantitative characters in relation to plant 
breeding. Indian J. Genet., 17, 318-328 (1957).

Qadir, M., E. Quillérou, V. Nangia, G. Murtaza, M. Singh, R.J. Thomas, P. Drechsel and A.D. Noble: Economics of salt-induced land degradation and restoration. Nat. Reso. Forum, 38, 282-295 (2014).

Rengasamy, P.: Soil processes affecting crop production in salt-affected soils. Funct. Plant Biol., 37, 613-620 (2010).

Saghai-Maroof, M.A., K.M. Soliman, R.A. Jorgensen and R.W. Allard: Ribosomal DNA spacer-length polymorphisms in barley: Mendelian inheritance, chromosomal location, and population dynamics. Pro. Nati. Aca. Sci., 81, 8014-8018(1984).
Shah, S.H., J. Gorham, B.P. Forster and R.G. J. Wyn: Salt tolerance in the Triticeae: The contribution of the $D$ genome to cation selectivity in hexaploid wheat. J. Exp. Bota., 38, 254-269 (1987).

Xu, B., S. Waters, C. S. Byrt, D. Plett, S. D. Tyerman, M. Tester, R. Munns, M. Hrmova and M. Gilliham: Structural variations in wheat HKT1; 5 underpin differences in $\mathrm{Na}^{+}$transport capacity. Cell. Mol. Life Sci., 75, 1133-1144 (2018).

Yadav, S., S. Yashveer, Y.P.S. Solanki and V. Singh: Phenotyping and microsatellite marker analysis of HD2851 (salt sensitive) $\times$ Kharchia 65 (salt tolerant) F2 population for salinity tolerance. Ind. J. Plant Physiol., 23, 57-64 (2017). 